\title{
Front Matter: Volume 6416
}

, "Front Matter: Volume 6416," Proc. SPIE 6416, Biomedical Applications of Micro- and Nanoengineering III, 641601 (27 December 2006); doi:

$10.1117 / 12.723882$

SPIE Event: SPIE Smart Materials, Nano- and Micro-Smart Systems, 2006, SPIE. Adelaide, Australia 


\section{PROGRESS IN BIOMEDICAL OPTICS AND IMAGING}

Vol. 7, No. 39

\section{Biomedical Applications of Micro- and Nanoengineering III}

Dan V. Nicolau

Chair/Editor

11-13 December 2006

Adelaide, Australia

Sponsored by

SPIE-The International Society for Optical Engineering

Cosponsored by

Australian Government Department of Defence, Defence Science and Technology

Organisation (Australia)

Office of Naval Research/Global Office of Naval Research Science and Technology (USA)

Air Force Office of Scientific Research/Asian Office of Aerospace Research and

Development (USA and Japan)

COSNe-ARC Complex Open Systems Research Network (Australia)

Australian Research Council Nanotechnology Network (Australia)

Published by

SPIE-The International Society for Optical Engineering

Volume 6416

The International Society

for Optical Engineering 
The papers included in this volume were part of the technical conference cited on the cover and title page. Papers were selected and subject to review by the editors and conference program committee. Some conference presentations may not be available for publication. The papers published in these proceedings reflect the work and thoughts of the authors and are published herein as submitted. The publisher is not responsible for the validity of the information or for any outcomes resulting from reliance thereon.

Disclaimer: The support provided for the conference by the co-sponsors is not intended as an endorsement of the contents of anything in these proceedings. Specifically, DSTO support is not intended to express or imply endorsement by the Australian Commonwealth Government; AFOSR/AOARD support is not intended to express or imply endorsement by the U. S. Federal Government; ONR Global support is not intended to express or imply endorsement by the U. S. Federal Government; COSNet support is not intended to express or imply endorsement by the Australian Research Council (ARC) or the Australian Commonwealth Government; ARC Nanotech Network support is not intended to express or imply endorsement by the Australian Research Council (ARC) or the Australian Commonwealth Government.

Please use the following format to cite material from this book:

Author(s), "Title of Paper," in Biomedical Applications of Micro- and Nanoengineering III, edited by Dan V. Nicolau, Proceedings of SPIE Vol. 6416 (SPIE, Bellingham, WA, 2007) Article CID Number.

ISSN 1605-7422

ISBN 9780819465245

Published by

SPIE-The International Society for Optical Engineering

P.O. Box 10, Bellingham, Washington 98227-0010 USA

Telephone 1 360/676-3290 (Pacific Time) · Fax 1 360/647-1445

http://www.spie.org

Copyright (c) 2007, The Society of Photo-Optical Instrumentation Engineers

Copying of material in this book for internal or personal use, or for the internal or personal use of specific clients, beyond the fair use provisions granted by the U.S. Copyright Law is authorized by SPIE subject to payment of copying fees. The Transactional Reporting Service base fee for this volume is $\$ 15.00$ per article (or portion thereof), which should be paid directly to the Copyright Clearance Center (CCC), 222 Rosewood Drive, Danvers, MA 01923. Payment may also be made electronically through CCC Online at http://www.copyright.com. Other copying for republication, resale, advertising or promotion, or any form of systematic or multiple reproduction of any material in this book is prohibited except with permission in writing from the publisher. The CCC fee code is $1605-7422 / 07 / \$ 15.00$.

Printed in the United States of America. 


\title{
Contents
}

\author{
ix Conference Committee \\ xi Sponsors
}

\author{
SESSION 1 NANOSCALE INTERACTIONS AND DEVICES I \\ 641602 DNA-sensors based on functionalized conducting polymers and quantum dots (Invited \\ Paper) [6416-01] \\ T. Kjällman, H. Peng, J. Travas-Sejdic, C. Soeller, Polymer Electronics Research Ctr., Univ. of \\ Auckland (New Zealand) \\ 641603 EB induced wetting of polypropylene surface [6416-02] \\ H. Sato, K. Iwata, T. Shimmi, M. Kanda, A. Tonegawa, Y. Nishi, Tokai Univ. (Japan) \\ 641604 Lateral force contrast for the detection of hydrophilic beads embedded within a PDMS \\ surface [6416-03] \\ P. Livingston, Monash Univ. (Australia); T. Tsuzuki, Swinburne Univ. of Technology (Australia); \\ R. I. Boysen, Monash Univ. (Australia); D. V. Nicolau, Monash Univ. (Australia) and Univ. of \\ Liverpool (United Kingdom)
}

\section{SESSION 2 NANOSCALE INTERACTIONS AND DEVICES II}

641605 Fluorescent intensity-based differential counting of FITC-doped silica nanoparticles: applications of CD4+ T-cell detection in microchip-type flowcytometers [6416-04] H. Yun, H. Bang, W. G. Lee, H. Lim, Seoul National Univ. (South Korea); J. Park, Digital Bio Technology, Inc. (South Korea); J. Lee, Seoul National Univ. (South Korea); A. Riaz, Univ. of California, Berkeley (USA); K. Cho, C. Chung, Digital Bio Technology, Inc. (South Korea); D.-C. Han, Seoul National Univ. (South Korea); J. K. Chang, Digital Bio Technology, Inc. (South Korea)

\footnotetext{
Pagination: Proceedings of SPIE follow an e-First publication model, with papers published first online and then in print and on CD-ROM. Papers are published as they are submitted and meet publication criteria. A unique, consistent, permanent citation identifier (CID) number is assigned to each article at the time of the first publication. Utilization of CIDs allows articles to be fully citable as soon they are published online, and connects the same identifier to all online, print, and electronic versions of the publication.

SPIE uses a six-digit CID article numbering system in which:

- The first four digits correspond to the SPIE volume number.

- The last two digits indicate publication order within the volume using a Base 36 numbering system employing both numerals and letters. These two-number sets start with 00, 01, 02, 03, 04, 05, 06, 07, 08, 09, 0A, 0B ... 0Z, followed by 10-1Z, 20-2Z, etc.

The CID number appears on each page of the manuscript. The complete citation is used on the first page, and an abbreviated version on subsequent pages.
} 
641606 Switchable surface coatings for control over protein adsorption [6416-05]

M. A. Cole, M. Jasieniak, Ian Wark Research Institute, Univ. of South Australia (Australia);

N. H. Voelcker, Flinders Univ. (Australia); H. Thissen, CSIRO Molecular and Health

Technologies (Australia); R. Horn, H. J. Griesser, Ian Wark Research Institute, Univ. of South

Australia (Australia)

641607 Calculation of low-frequency vibrational modes of biologically important isomers [6416-06]

I. Jones, T. J. Rainsford, B. M. Fischer, D. Abbott, The Univ. of Adelaide (Australia)

641608 Enzyme electrodes immobilized on hetero-structured metallic nanowire array for glucose sensing [6416-08]

H. Yoon, D. Deshpande, R. R. Chintakuntla, V. K. Varadan, Univ. of Arkansas (USA)

SESSION 3 BIOMEMS

64160A Development of blood extraction pump by shape memory alloy actuator for bio-MEMS

[6416-10]

K. Tsuchiya, Y. Shimazu, Tokai Univ. (Japan); Y. Uetsuji, E. Nakamachi, Osaka Institute of Technology (Japan)

64160B Compensation of nonlinearities in a piezoelectric stack actuator with application in intracytoplasmic sperm injection [6416-11]

A. S. Putra, K. K. Tan, T. H. Lee, S. K. Panda, S. N. Huang, S. Zhao, National Univ. of Singapore (Singapore)

64160C Development of the new shape PZT ceramics sounder suitable for a sound source of artificial larynx [6416-12]

K. Ooe, R. Kanetake, Y. Sugio, A. Tanaka, Ritsumeikan Univ. (Japan)

64160D Development of a blood vessel searching device for HMS [6416-14]

T. Kuroda, Osaka Institute of Technology (Japan); T. Uenoya, ASTEM Research Institute of Kyoto (Japan); K. Tsuchiya, Tokai Univ. (Japan); Y. Uetsuji, E. Nakamachi, Osaka Institute of Technology (Japan)

\section{SESSION 4 MICROFLUIDICS I}

64160E Active control for droplet-based microfluidics (Invited Paper) [6416-15]

T. H. Ting, Y. F. Yap, N.-T. Nguyen, T. N. Wong, J. C. Kiong Chai, Nanyang Technological Univ. (Singapore); L. Yobas, Institute of Microelectronics (Singapore)

64160F Novel microfluidic device for cell characterization by impedance spectroscopy [6416-16] C. lliescu, Institute of Bioengineering and Nanotechnology (Singapore); D. Poenar, Nanyang Technological Univ. (Singapore); K. J. Leck, Institute of Bioengineering and Nanotechnology (Singapore); M. Carp, Nanyang Technological Univ. (Singapore): A. J. Pang, F. C. Loe, Institute of Bioengineering and Nanotechnology (Singapore); F. S. lliescu, Republic Polytechnic (Singapore) 
$64160 \mathrm{G}$ An electromechanical filter for bioparticles trapping [6416-17]

C. Iliescu, G. Xu, Institute of Bioengineering and Nanotechnology (Singapore); F. E. H. Tay, Institute of Bioengineering and Nanotechnology (Singapore) and National Univ. of Singapore (Singapore); P. L. Ong, Institute of Bioengineering and Nanotechnology (Singapore)

\section{SESSION $5 \quad$ MICROFLUIDICS II}

64160J Detection of inorganic ions on a capillary electrophoresis microchip using a conductivity technique [6416-20]

K. Petkovic-Duran, Y. Zhu, A. Swallow, N. Noui-Mehidi, P. Leech, F. Glenn, CSIRO

Microfluidics Lab., CSIRO Division of Manufacturing and Materials Technology (Australia)

64160K Capillary flow in polymer microfluidic chips [6416-21]

Y. Zhu, K. Petkovic-Duran, CSIRO Microfluidics Lab., CSIRO Division of Manufacturing and Materials Technology (Australia)

64160L Blood flow assessment in a heart with septal defect based on optical flow analysis of magnetic resonance images [6416-22]

K. Wong, Univ. of Adelaide (Australia); P. Kuklik, Warsaw Univ. of Technology (Poland);

R. M. Kelso, S. G. Worthley, P. Sanders, J. Mazumdar, D. Abbott, Univ. of Adelaide (Australia)

$64160 \mathrm{M}$ Microfluidic chip with optical sensor for rapid detection of nerve agent Sarin in water samples [6416-23]

H. Y. Tan, DSO National Labs. (Singapore); N.-T. Nguyen, Nanyang Technological Univ. (Singapore); W. K. Loke, Y. T. Tan, DSO National Labs. (Singapore)

$64160 \mathrm{~N}$ The culture of human embryonic stem cells in microchannel perfusion bioreactors [6416-24]

N. Korin, A. Bransky, U. Dinnar, S. Levenberg, Technion (Israel)

641600 A microfabricated bio-sensor for erythrocytes deformability and volume distributions analysis [6416-25]

A. Bransky, N. Korin, Y. Nemirovski, U. Dinnar, Technion (Israel)

64160P An electrically controlled micromachined drug delivery device employing two silicon wafers [6416-27]

R. Rajan, S. M. Aziz, Univ. of South Australia (Australia); T. Vaithianathan, Ctr. for Advanced Manufacturing Research, Univ. of South Australia (Australia)

\section{SESSION 6 MODELLING AND COMPUTATION}

64160Q A biologically inspired model for signal compression [6416-28]

M. D. McDonnell, D. Abbott, Ctr. for Biomedical Engineering, The University of Adelaide (Australia) 
64160R Toward 'smart' DNA microarrays: algorithms for improving data quality and statistical inference [6416-29]

D. J. G. Bakewell, Univ. of Liverpool (United Kingdom); E. Wit, Lancaster Univ. (United Kingdom)

64160S Computing with motile bio-agents [6416-30]

D. V. Nicolau, Jr., Mathematical Institute, Univ. of Oxford (United Kingdom); K. Burrage, Advanced Computational Modelling Ctr., Univ. of Queensland (Australia); D. V. Nicolau, Dept. of Electrical and Electronic Engineering, Liverpool Univ. (United Kingdom)

64160T Advanced monitoring systems for biological applications in marine environments [6416-31] U. Cella, Politecnico di Milano (Italy); T. Chiffings, The Univ. of Queensland (Australia); A. Gandelli, F. Grimaccia, Politecnico di Milano (Italy); R. W. Johnstone, The Univ. of Queensland (Australia); R. E. Zich, Politecnico di Milano (Italy)

SESSION 7 TERAHERTZ TECHNOLOGY AND DEVICES

$64160 \mathrm{U}$ T-ray biosensing: a versatile tool for studying low-frequency intermolecular vibrations (Invited Paper) [6416-32]

B. M. Fischer, M. Franz, Ctr. for Biomedical Engineering, The Univ. of Adelaide (Australia) and Albert-Ludwigs-Univ. Freiburg (Germany); D. Abbott, Ctr. for Biomedical Engineering, The Univ. of Adelaide (Australia)

$64160 \mathrm{~V}$ Investigation on improving the noise performance of T-ray liquid spectroscopy via doublemodulated differential time-domain spectroscopy [6416-33]

J. Balakrishnan, B. M. Fischer, S. P. Mickan, D. Abbott, Ctr. for Biomedical Engineering, The Univ. of Adelaide (Australia)

64160W Molecular and structural preservation of dehydrated bio-tissue for THz spectroscopy [6416-34]

G. M. Png, Ctr. For Biomedical Engineering, The Univ. of Adelaide (Australia); J. W. Choi, Ctr. For Terahertz Research, Rensselaer Polytechnic Institute (USA); I. Guest, NYS Dept. of Health (USA); B. W. Ng, S. P. Mickan, D. Abbott, Ctr. For Biomedical Engineering, The Univ. of Adelaide (Australia); X. Zhang, Ctr. For Terahertz Research, Rensselaer Polytechnic Institute (USA)

64160X Classification of terahertz data as a tool for the detection of cancer [6416-35]

M. J. Berryman, T. Rainsford, Ctr. for Biomedical Engineering, The Univ. of Adelaide (Australia)

\section{POSTER SESSION}

64160Y Single-cell impedance spectroscopy: maximum length sequence analysis [6416-18] T. Sun, N. G. Green, S. Gawad, H. Morgan, Univ. of Southampton (United Kingdom) 
641602 A wireless sensor for detecting gastroesophageal reflux [6416-38]

T. Ativanichayaphong, Automation \& Robotics Research Institute, The Univ. of Texas at Arlington (USA); W.-D. Huang, J. Wang, Dept. of Electrical Engineering, The Univ. of Texas at Arlington (USA); S. M. N. Rao, Automation \& Robotics Research Institute, The Univ. of Texas at Arlington (USA); H. F. Tibbals, Bioinstrumentation Resource Ctr., The Univ. of Texas Southwestern Medical Ctr. at Dallas (USA); S.-J. Tang, S. Spechler, Dept. of Medicine, The Univ. of Texas Southwestern Medical Ctr. at Dallas (USA); H. Stephanou, Automation \& Robotics Research Institute, The Univ. of Texas at Arlington (USA); J.-C. Chiao, Automation \& Robotics Research Institute, The Univ. of Texas at Arlington (USA) and Dept. of Electrical Engineering, The Univ. of Texas at Arlington (USA)

641610 Self-assembled magnosilicate nanocapturer for the in-situ separation of human DNA and proteins [6416-39]

J. H. Chang, K. J. Kim, Korea Institute of Ceramic Engineering and Technology (South Korea)

641611 Functional bone-mimetic scaffolds of bicontinuous, thermo-responsive L3-phase silica/hydroxyapatite nanocomposites [6416-40]

J. H. Chang, K. J. Kim, Korea Institute of Ceramic Engineering and Technology (South Korea)

641612 Electrical detection of biomolecules in a PDMS micro-fluidic channel using a MOSFET-type biosensor [6416-41]

J.-K. Shin, D.-S. Kim, Kyungpook National Univ. (South Korea); G. Lim, Pohang Univ. of Science and Technology (South Korea); S. Shoji, Waseda Univ. (Japan)

641613 Encapsulation of cell into monodispersed hydrogels on microfluidic device [6416-42] C.-H. Choi, J.-H. Lee, H.-W. Shim, N.-R. Lee, J.-H. Jung, T.-H. Yoon, D.-P. Kim, C.-S. Lee, Chungnam National Univ. (South Korea)

641614 Rapid bio-patterning method based on the fabrication of PEG microstructures and layerby-layer polymeric thin film [6416-43]

H.-W. Shim, J.-H. Lee, C.-H. Choi, H.-M. Song, B.-Y. Kim, D.-P. Kim, C.-S. Lee, Chungnam National Univ. (South Korea)

Author Index 
Downloaded From: https://www.spiedigitallibrary.org/conference-proceedings-of-spie on 26 Apr 2023

Terms of Use: https://www.spiedigitallibrary.org/terms-of-use 


\title{
Conference Committee
}

\author{
Symposium Chairs
}

Joe G. Shapter, Flinders University of South Australia (Australia)

Vijay K. Varadan, University of Arkansas (USA)

Derek Abbott, The University of Adelaide (Australia)

Conference Chair

Dan V. Nicolau, The University of Liverpool (United Kingdom)

Conference Cochairs

Joe G. Shapter, Flinders University of South Australia (Australia)

Derek Abbott, The University of Adelaide (Australia)

Program Committee

Maan M. Alkaisi, University of Canterbury (New Zealand)

John M. Bell, Queensland University of Technology (Australia)

Shin-Ho Chung, Australian National University (Australia)

Paul Dan A. Cristea, Universitatea Politehnica Bucharest (Romania)

Piotr Grodzinski, National Institutes of Health (USA)

Min Gu, Swinburne University of Technology (Australia)

Abraham P. Lee, University of California/Irvine (USA)

Torsten Lehmann, University of New South Wales (Australia)

Nigel H. Lovell, University of New South Wales (Australia)

Don McNaughton, Monash University (Australia)

Gotfried Otting, The Australian National University (Australia)

Tamath J. Rainsford, The University of Adelaide (Australia)

Takahisa Taguchi, National Institute of Advanced Industrial Science and Technology (Japan)

\section{Session Chairs}

$1 \quad$ Nanoscale Interactions and Devices I

Dan V. Nicolau, The University of Liverpool (United Kingdom)

2 Nanoscale Interactions and Devices II

Dan V. Nicolau, The University of Liverpool (United Kingdom)

3 BioMEMS

Dan V. Nicolau, The University of Liverpool (United Kingdom) 
Microfluidics I

Hywel Morgan, University of Southampton (United Kingdom)

5 Microfluidics II

Dan V. Nicolau, The University of Liverpool (United Kingdom)

6 Modelling and Computation

Ciprian I. Iliescu, Institute of Bioengineering and Nanotechnology (Singapore)

$7 \quad$ Terahertz Technology and Devices

Tamath J. Rainsford, The University of Adelaide (Australia) 


\section{Major Co-sponsor}

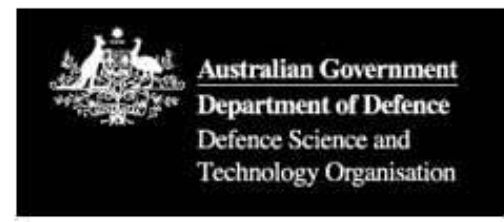

\section{Co-sponsors}
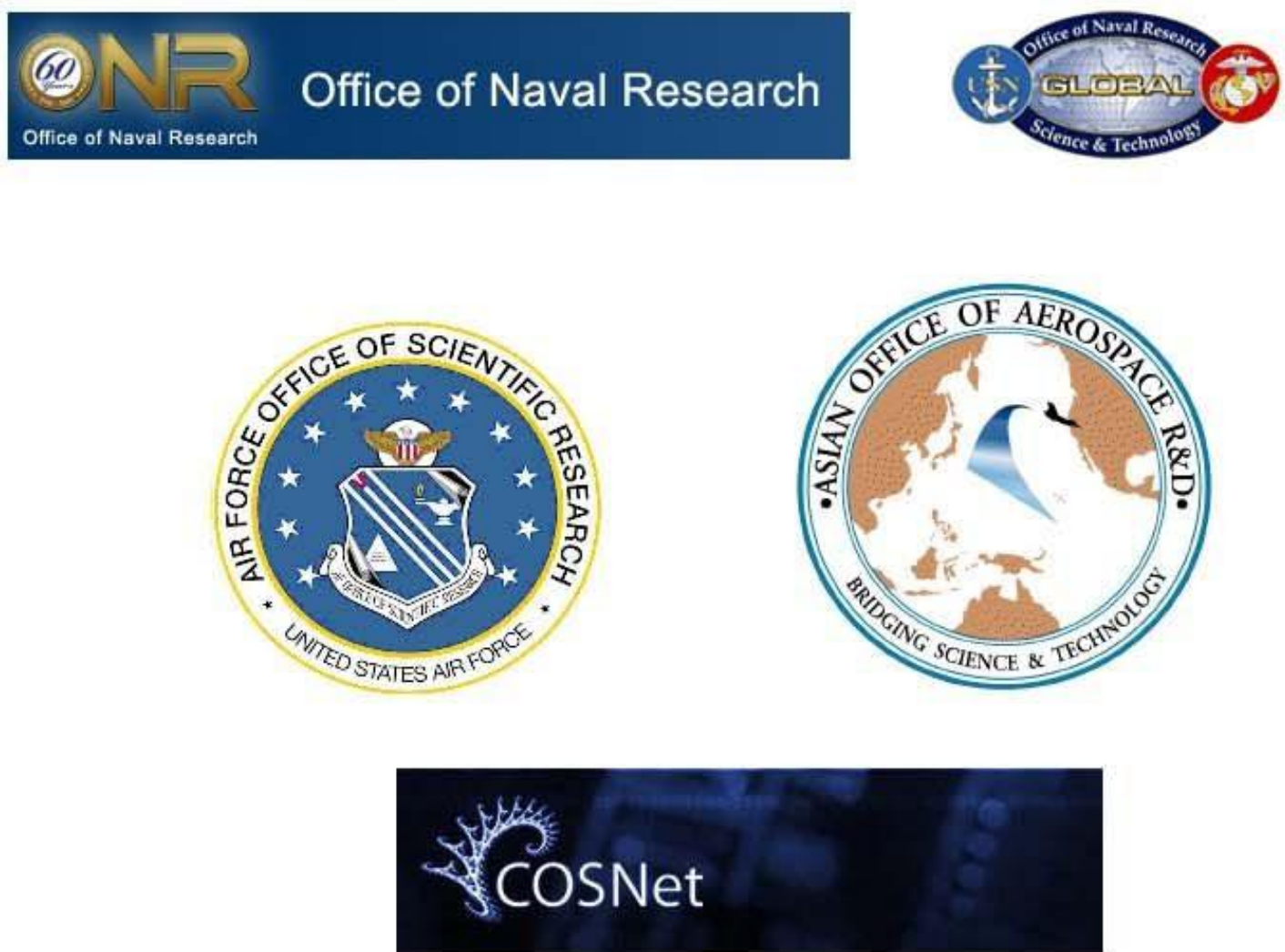

ARC Complex Open Systems Research Network

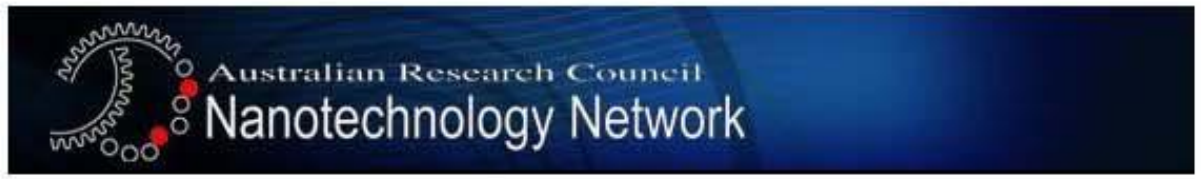

We wish to thank the co-sponsors for their contribution to the success of the conference:

Defence Science and Technology Organisation (DSTO)

Air Force Office of Scientific Research, Asian Office of Aerospace Research and Development

Office of Naval Research Global

ARC Complex Open Systems Research Network

ARC Nanotechnology Network 
Downloaded From: https://www.spiedigitallibrary.org/conference-proceedings-of-spie on 26 Apr 2023

Terms of Use: https://www.spiedigitallibrary.org/terms-of-use 